\title{
The Reception of Geoffrey of Monmouth in Wales
}

\author{
Ben Guy
}

The influence of Geoffrey of Monmouth on medieval Welsh vernacular literature was pervasive. Since many of the themes, characters, and events in Geoffrey's work had been drawn in the first instance from stories and texts emanating from medieval Wales, it was natural that the Welsh should feel an immediate affinity with Geoffrey's writings. Although Geoffrey openly disparages the latter-day Welsh at the end of the De gestis Britonum, he did succeed in providing them with a long and glorious past in which the ancestors of the Welsh, the Britons, were associated with the original founding and naming of the kingdom of Britain. Geoffrey helped to confirm prior Welsh historical assumptions and to provide a coherent organizational framework for the mass of inherited Welsh literary-historical tradition.

An early manifestation of Geoffrey's influence may be seen in the pedigree of the kings of Gwynedd and Deheubarth, which absorbed some of Geoffrey's legendary kings of Britain within only a few decades of the completion of Geoffrey's $D G B$ around 1138. ${ }^{1}$ But it was only with the translation of Geoffrey's $D G B$ into medieval Welsh that his work began to infiltrate popular conceptions of Welsh and British history at a more fundamental level. The translation process may have begun with an attempt to identify Welsh equivalents for the many characters named in the work, as may be evidenced in a poem composed by Cynddelw Brydydd Mawr around $1187 .^{2}$ By no later than $c .1250$, however, there had been several attempts at translating the entirety of Geoffrey's $D G B$ into Welsh. These translations are known collectively as Brut y Brenhinedd ("History of the Kings").

1 B. Guy, "Gerald and Welsh Genealogical Learning", in G. Henley and A.J. McMullen (eds.), Gerald of Wales: New Perspectives on a Medieval Writer and Critic, Cardiff, 2018, pp. 47-61, at pp. 50-55.

2 P. Sims-Williams, Rhai Addasiadau Cymraeg Canol o Sieffre o Fynwy [Some Middle Welsh adaptations of Geoffrey of Monmouth], Aberystwyth, 2011, pp. 6-9; B. Guy, "Constantine, Helena, Maximus: on the Appropriation of Roman History in Medieval Wales, c.8oo-1250", Journal of Medieval History 44 (2018), 381-405, at pp. 400-01. 
At least four versions of Brut y Brenhinedd survive from the 13th century: the Llanstephan 1 version (earliest manuscript $s$. xiii ${ }^{\text {med }}$ ), ${ }^{3}$ the Peniarth 44 version (earliest manuscript $s$. xiii ${ }^{\text {med }}$ ), the Dingestow version (earliest manuscript s. xiii $\left.{ }^{2}\right),{ }^{4}$ and the Liber Coronacionis Britanorum (earliest manuscript s. xiii/xiv). ${ }^{5}$ Other versions appeared later: the idiosyncratic Cotton Cleopatra version (earliest manuscript c.1330) ${ }^{6}$ and the derivative Red Book of Hergest version (earliest manuscripts $s$. xiv $\left.^{2}\right),{ }^{7}$ both probably prepared in the first half of the 14th century, and Brut Tysilio (earliest manuscript $s$. xvi ${ }^{\text {med}}$ ), an abbreviation redacted in the $15^{\text {th }}$ or early 16 th century. ${ }^{8}$ None of these versions is entirely independent of the others. ${ }^{9}$ For example, they all draw upon the same translation of the $P M$, one seemingly created prior to the first full translation of the $D G B$ itself..$^{10}$ Although it is therefore clear that successive redactors of Bruty Brenhinedd were guided by the work of their predecessors, supported by

3 Discussed, with edited excerpts, in Brut y Brenhinedd: Llanstephan MS. 1 Version, ed. B.F. Roberts (Mediaeval and Modern Welsh Series, 5), Dublin, 1971, and again in B. Roberts, "Brut y Brenhinedd ms. National Library of Wales, Llanstephan 1 version", in H. Tétrel and G. Veysseyre (eds.), L'Historia regum Britannie et les "Bruts" en Europe, Tome I, Traductions, adaptations, réappropriations $\left(X I I^{e}-X V I^{e}\right.$ siècle) (Rencontres 106, Civilisation médiévale, 12), Paris, 2015, pp. 71-8o.

4 Edited in Brut Dingestow, ed. H. Lewis, Cardiff, 1942, and discussed in B. Roberts, "Fersiwn Dingestow o Brut y Brenhinedd" [The Dingestow version of Brut y Brenhinedd], BBCs 27 $\left(197^{6-78)}, 331-61\right.$.

$5 \quad$ Edited and discussed in Liber Coronacionis Britanorum, ed. P. Sims-Williams, 2 vols., Aberystwyth, 2017.

6 Edited and translated in Bruty Brenhinedd:Cotton Cleopatra Version, ed. and trans.J.J. Parry, Cambridge, MA, 1937 (the only full translation of Bruty Brenhinedd into English) and discussed in B.F. Roberts, "Ystoriaeu Brenhinedd Ynys Brydeyn: a fourteenth-century Welsh Brut", in J.F. Eska (ed.), Narrative in Celtic Tradition: Essays in Honor of Edgar M. Slotkin (cSANA Yearbook, 8-9), Hamilton, NY, 2011, pp. 215-27, and in P.-Y. Lambert, "À propos de la traduction galloise du ms. London, British Library, Cotton Cleopatra B.V", in Tétrel and Veysseyre (eds.), L'Historia Regum Britannie, pp. 81-103.

Text from the Red Book of Hergest edited in The Text of the Bruts from the Red Book of Hergest, ed.J. Rhŷs and J.G. Evans, Oxford, 189o, and the version is discussed in B.F. Roberts, "The Red Book of Hergest Version of Brut y Brenhinedd", Studia Celtica 12/13 (1977-78), $147-86$.

8 Discussed in B.F. Roberts, Brut Tysilio, Swansea, 1980.

9 For a recent discussion of the textual relationships, see Sims-Williams, Rhai Addasiadau, which is updated, abbreviated, and translated into English in id., "The Welsh Versions of Geoffrey of Monmouth's 'History of the Kings of Britain'”, in A. Harlos and N. Harlos (eds.), Adapting Texts and Styles in a Celtic Context: Interdisciplinary Perspectives on Processes of Literary Transfer in the Middle Ages. Studies in Honour of Erich Poppe, Münster, 2016, pp. 53-74.

10 B. Roberts, "Copiau Cymraeg o Prophetiae Merlini" [Welsh copies of Prophetiae Merlini], National Library of Wales Journal 20 (1977), 14-39. 
continued deferral to multiple versions of the original Latin text, it nevertheless remains true that each version has its own distinct flavor." ${ }^{11}$

The proliferation of versions of Brut y Brenhinedd is indicative of the high popularity attained by the text. It survives in more medieval Welsh manuscripts than any text aside from the Laws of Hywel Dda. ${ }^{2}$ Many of these manuscripts were written in Cistercian monasteries, which became the central nodes of Welsh-language culture between the 13th and 16th centuries. Through its Welsh versions, Geoffrey's $D G B$ had a profound effect on other types of Welsh literature. It inspired the writing of the short prose tale Lludd and Llefelys, which is often found inserted into copies of Brut y Brenhinedd (though it is also found independently)..$^{13}$ In some manuscripts, Brut y Brenhinedd became the centerpiece for a sequence of Welsh prose texts telling the history of the Britons from the fall of Troy to 1282: it is often prefaced by Ystorya Dared, the medieval Welsh version of Dares Phrygius's The Fall of Troy, and followed by Brut y Tywysogyon ("History of the Princes"), which became the standard vernacular account of Welsh history from $c .682$ to $1282 .{ }^{14}$ The original compiler of the latter text clearly conceived the work as a continuation of Geoffrey's History, because the annalistic account begins explicitly with the death of Cadwaladr and the Britons' loss of sovereignty over Britain. Bruty Brenhinedd similarly infiltrated the triadic and genealogical literature, to the extent that new versions of those types of texts tended to follow Geoffrey's account of the British past in preference to other accounts. ${ }^{15}$ It is no surprise that even the genealogist of Llywelyn ap Gruffudd, prince of Gwynedd (1255-82), should be confident that a reference to a genealogical variant found in the "Hystoria" would be understood, without further specification, as a reference to Geoffrey's $D G B .{ }^{16}$

By the 14th and 15th centuries, Geoffrey's account of British history had been normalized to a considerable degree in Welsh writing. This is demonstrated by the constant references to events and characters of Geoffrey's $D G B$

11 The characteristics of the versions are summarized in Brut y Brenhinedd, ed. Roberts, pp. xxiv-xxxi.

12 D. Huws, Medieval Welsh Manuscripts, Aberystwyth, 20oo, pp. 12 and 40-41.

13 Edited in Cyfranc Lludd and Llefelys, ed. B.F. Roberts (Mediaeval and Modern Welsh Series, 7), Dublin, 1975, and translated in The Mabinogion, trans. S. Davies, Oxford, 2007, pp. $111-15$.

14 H. Fulton, "Troy Story: The Medieval Welsh Ystorya Dared and the Brut Tradition of British History", in J. Dresvina and N. Sparks (eds.), The Medieval Chronicle VII, Amsterdam, 2011, pp. 137-50.

15 Trioedd Ynys Prydein: The Triads of the Island of Britain, ed. and trans. R. Bromwich, 4th ed., Cardiff, 2014, pp. lxvi-lxix.

16 D.E. Thornton, "A Neglected Genealogy of Llywelyn ap Gruffudd", cMcs 23 (1992), 9-23, at pp. $13^{-15}$. 
in strict-meter poetry. Geoffrey's $P M$ became similarly integrated into mainstream poetic, and especially prophetic, discourse, supported no doubt by the 13th-century Welsh commentary on the text. ${ }^{17}$ Likewise, the 14th-century Welsh prose text on the birth of Arthur twice refers its readers to "Ystoria y Brytaniett" ("The History of the Britons") for further information on Uthyr's death, and draws many incidental details from the Brut. ${ }^{18}$ The trend continued into the 15th century. The text concerning the "Twenty-Four Knights of Arthur's Court" contains an indiscriminate blend of elements from Welsh legend, Geoffrey's $D G B$, the Welsh-language Y Seint Greal (translated in the 14th century from two French prose Grail romances), and the 13th-century French Vulgate cycle of Arthurian romances. ${ }^{19}$ By the end of the 15th century, Geoffrey's account of British history still provided the undisputed master narrative for the Welsh past and for the literary works predicated on it, and it continued to find adherents in Wales down to the 19th century. ${ }^{20}$

17 R.W. Evans, "Prophetic Poetry", in A.O.H. Jarman and G.R. Hughes (eds.), A Guide to Welsh Literature 1282-c. 1550: Volume II, rev. D. Johnston, Cardiff, 1997, pp. 256-74, esp. pp. 262 and 264; B. Roberts, "Esboniad Cymraeg ar broffwydoliaeth Myrddin" [A Welsh commentary on the prophecy of Merlin], BBCS 21 (1964-66), 277-300.

18 C. Lloyd-Morgan, "Blending and Rebottling Old Wines: the Birth and Burial of Arthur in Middle Welsh", in Harlos and Harlos (eds.), Adapting Texts and Styles, pp. 155-75, at pp. 158-6o.

19 Trioedd Ynys Prydein, ed. and trans. Bromwich, pp. cx-cxiii and 266-69.

20 For the debate about Geoffrey's authenticity in Wales down to the 19th century, see Bruty Brenhinedd, ed. Roberts, pp. $55^{-74}$. 